\title{
Forensic DNA Databank Malaysia (FDDM): 100,000 DNA Profiles Achievement
}

\author{
Mahaya Abdul Rahman ${ }^{1, ~ *, ~ S i t i ~ A f i f a h ~ I s m a i l ~}{ }^{1}$, Tang Ngat Ngoh ${ }^{1}$, Hussein Omar Khan ${ }^{1}$, \\ Nor Aidora Saedon" ${ }^{2}$, Nurul Hazirah Mat Lazim² \\ ${ }^{1}$ DNA Databank Division (D13), Criminal Investigation Department, Royal Malaysia Police, Selangor, Malaysia \\ ${ }^{2}$ Forensic DNA Division, Department of Chemistry Malaysia, Selangor, Malaysia \\ Email address: \\ mahaya2910@gmail.com (M. A. Rahman), fifah1350@gmail.com (S. A. Ismail), lisarmp@gmail.com (T. N. Ngoh), \\ husseinok@rmp.gov.my (H. O. Khan),dora@kimia.gov.my (N. A. Saedon), nurulhazirah@kimia.gov.my (N. H. M. Lazim) \\ ${ }^{*}$ Corresponding author
}

\section{To cite this article:}

Mahaya Abdul Rahman, Siti Afifah Ismail, Tang Ngat Ngoh, Hussein Omar Khan, Nor Aidora Saedon, Nurul Hazirah Mat Lazim. Forensic DNA Databank Malaysia (FDDM): 100,000 DNA Profiles Achievement. Science, Technology \& Public Policy.

Vol. 5, No. 1, 2021, pp. 47-53. doi: 10.11648/j.stpp.20210501.15

Received: November 4, 2020; Accepted: April 24, 2021; Published: May 8, 2021

\begin{abstract}
Since 2013 to 2018, many successes have been achieved through the implementation of FDDM by the DNA Databank Division (D13) Royal Malaysia Police (RMP) and the Department of Chemistry Malaysia (KIMIA). Amongst those successes was the increase in the number of DNA samples analyzed by 31,095 for the year 2018; as compared to 2017 which was only 11,359; and now the total number of DNA samples that have been successfully analyzed by (D13) was 96,037. With the full commitment and cooperation given by both RMP and KIMIA, the DNA profiles in the FDDM System have touched the remarkable number of 100,000 in 2018. This is a great success for both agencies. The matching cases also showed an increase in number and by year 2018, there were 33 cases and it is expected to undergo continual increment from year to year. The MS ISO/ IEC 17025:2005 Accreditation for RMP DNA Laboratory is currently gearing up for a new version of MS ISO/ IEC 17025:2017 Accreditation, which is scheduled to be implemented. Spanning the 21st century, RMP and KIMIA are always positive in ensuring that the direction of FDDM constantly evolves from time to time in line with the rapid development of DNA Technology.
\end{abstract}

Keywords: DNA Database, DNA Legislation, Matching Case, DNA Analysis

\section{Introduction}

In Malaysia, the Department of Chemistry Malaysia (KIMIA) has initiated Forensic DNA profiling in 1994. The DNA profiles obtained from crime scenes would be compared to the suspect arrested (if any). There was no database then, therefore the matching was done on a case by case basis.

From INTERPOL's 190 member countries, approximately 87 countries use DNA profiling in criminal investigations, whereby 71 countries own a national DNA database, including Malaysia. Most of the countries with a DNA database have specific DNA databases legislation. The estimated global total of DNA profiles reported by INTERPOL is 90 million.
As a result of successful collaboration between Royal Malaysia Police (RMP) and Department of Chemistry Malaysia (KIMIA), FDDM has been proven to be one of the best crimes solving tools. In 2018, a total of 100,000 DNA profiles have been successfully uploaded to the FDDM System and 33 DNA matchings have been successfully obtained $[1,7,12]$.

In 2013, there are only 13,102 DNA profiles in FDDM and only 2 matches were successfully obtained by DNA databank officers. In 2014, 40,597 DNA profiles were uploaded which became a total of 53,699 DNA profiles in the FDDM. Eventually, the number increased to 100,000 after almost 6 years. The DNA profile increased slowly due to the financial constraints for reagents and consumables procurement. (Figure 1). 


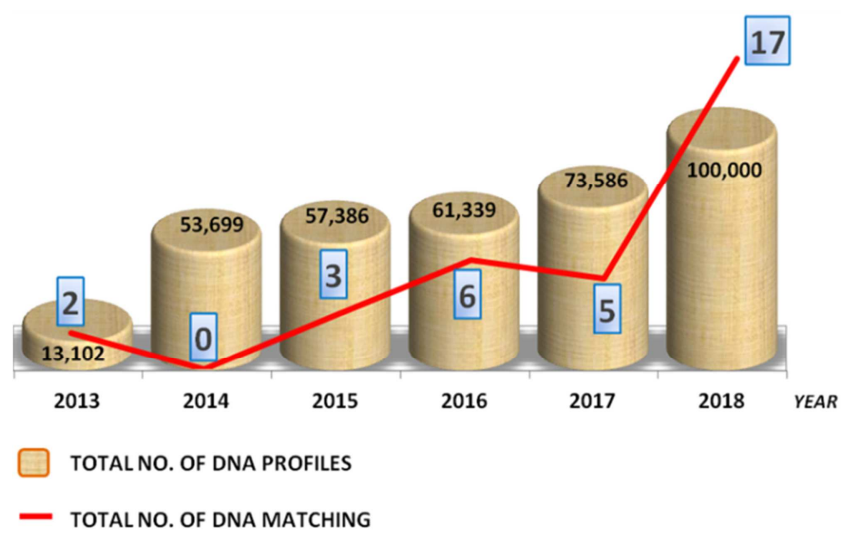

Figure 1. Total Number of DNA profiles in FDDM and Total Number of DNA Matching (2013-2018).

These successes are an excellent achievement since the establishment of FDDM in Malaysia. This proves that FDDM has aided and solved crime including cold cases. However, the DNA database is not only a tool for solving crimes but also plays a role in crime prevention and can be used to monitor repeat offenders as well as to avoid false accusations $[1,9,11,15]$.

\section{Background: Establishment, DNA Act, Collaboration Between RMP \& KIMIA}

\subsection{Establishment of Forensic DNA Databank Malaysia (FDDM)}

The idea of establishing FDDM arise in 2001, based on the Malaysia Cabinet's decision to hire foreign experts to assist in solving the unsolved murder cases. Datuk Seri Rais Yatim, who was then a Minister in the Prime Minister's Department, had proposed to establish the DNA databank as one of the counter-measures and efforts to solve the problem (Figure 2).

For the purpose of taking individual DNA samples (Suspected Persons Index), a designated room, which is a OneStop Forensic Identification Centre, was set up at all Police Districts in Malaysia. This designated room is to cater the systematic collection and preserving the integrity of the DNA samples as the room is secured and monitored through CCTV.

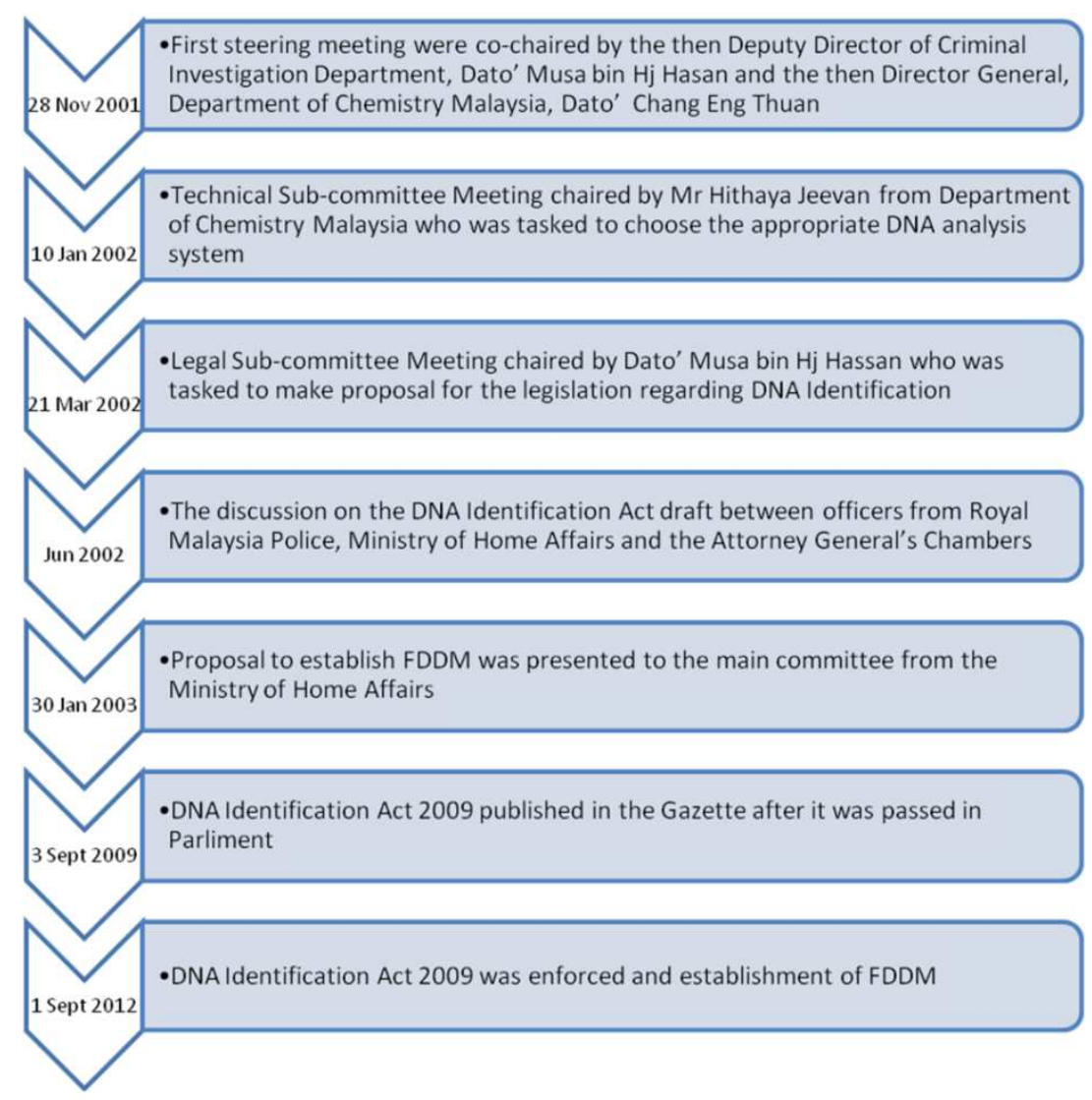

Figure 2. FDDM timeline.

\subsection{Malaysia DNA Legislation: DNA Identification Act 2009 (Act 699)}

DNA Identification Act 2009 is an act to provide for the establishment of Forensic DNA Databank Malaysia (FDDM), the taking of DNA samples, forensic DNA analysis, the use of DNA profiles and information in relation thereto, and for matters connected therewith.

The implementation and legislation are different between countries and it may vary from state to state, as well as the size of the population like in the United States and the United Kingdom. [1, 5]. The DNA databases on the understanding that the legislation are specifically for controlled access and 
shall not reveal somatic or behavioral traits of a person [2].

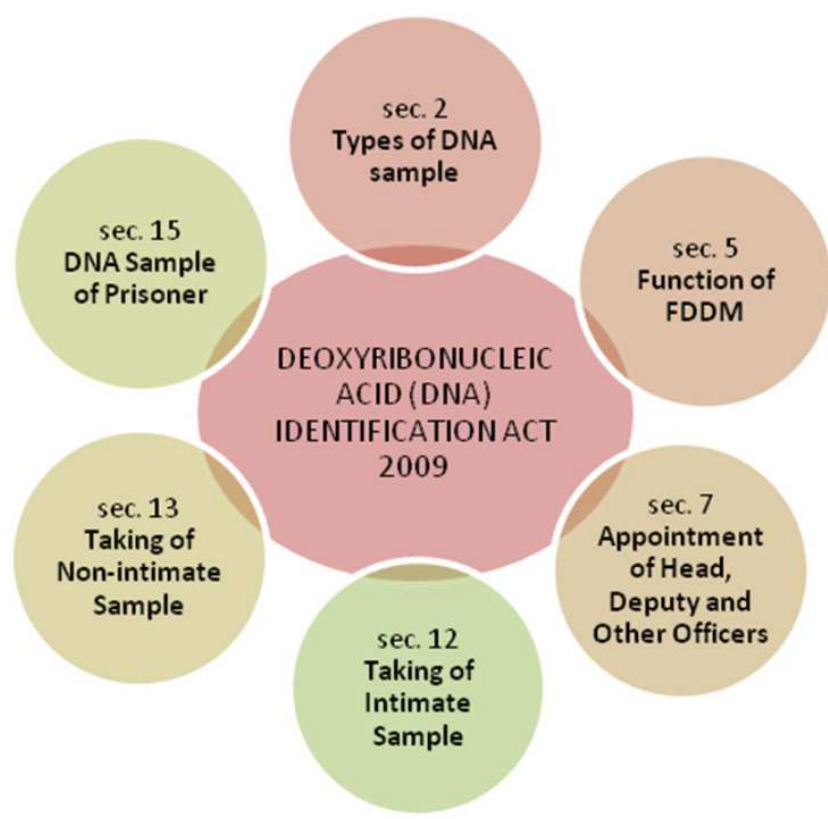

Figure 3. Important sections under the DNA Identification Act 2009.

In Malaysia, the authority to manage the database and carry out the DNA analysis is entirely by a government officer either from the RMP or KIMIA. They are appointed by the Minister of Home Affair and this has been mentioned under a few sections such as in Section 5, 6, 7 and 8 in the
DNA Identification Act 2009 [3].

The power to take samples is clarified under Sections 12 and 13 of Act 699 . It has been stipulated that permission from a police officer at least with the rank Deputy Superintendent Police and above must be obtained prior to the taking of intimate samples or non-intimate samples. Referring to Act 699, the DNA samples are divided into two categories which is a nonintimate sample and intimate samples. Non-intimate sample means a sample of hair except pubic hair, a sample taken from the nail, a sample taken from any part of a person's body except any part that is categorized as an intimate sample [3].

Intimate samples are defined as a sample of blood, semen, urine, pubic hair, tissue or fluid taken from a person's body and also swab taken from any part of a person's genital genitals (including pubic hair) from a person's body orifice other than the mouth.

Samples should be taken by a gazetted medical officer for the following persons:

a) Somebody that is suspected of having committed an offence

b) Detainee

c) Drug dependents

In addition, under Section 15 of this act has described that the power to take DNA samples of prisoners where an intimate sample or a non-intimate sample may be taken for forensic DNA analysis from any person who is serving his or her term of imprisonment in connection with an offence of which he or she has been convicted [3-5].

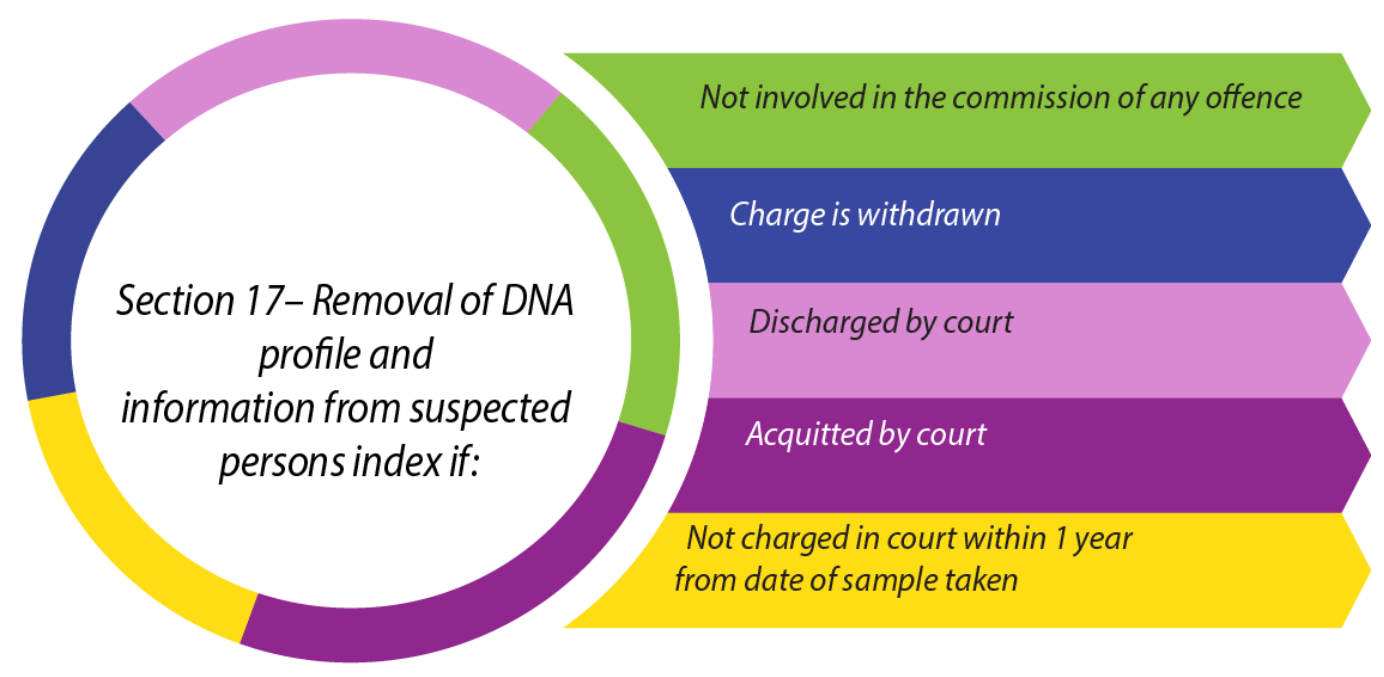

Figure 4. Section 17 DNA Identification Act (Act 699).

Under Section. 3 (3) Act 699 stated that there are seven indices consist in FDDM:

1. Crime Scene: DNA profiles from any part of the person or any physical evidence collected from any location that may be associated with a committed crime.

2. Suspected: DNA profiles taken from a person reasonably suspected of having committed an offence and includes suspects who have not been charged in any court for any offence.

3. Convicted Offender: DNA profiles taken from a person convicted of any offence under any written law.
4. Detainee: DNA profiles taken from a detainee.

5. Drug Dependents: DNA Profiles taken from a drug dependent.

6. Missing Persons: DNA profiles are taken from the body or part of the body of an unidentified deceased person, anything worn or carried by a missing person or the next of kin of a missing person.

7. Voluntary: DNA profiles taken from a person who volunteers to give their DNA profile for FDDM storage including from victims of any offences [2]. 


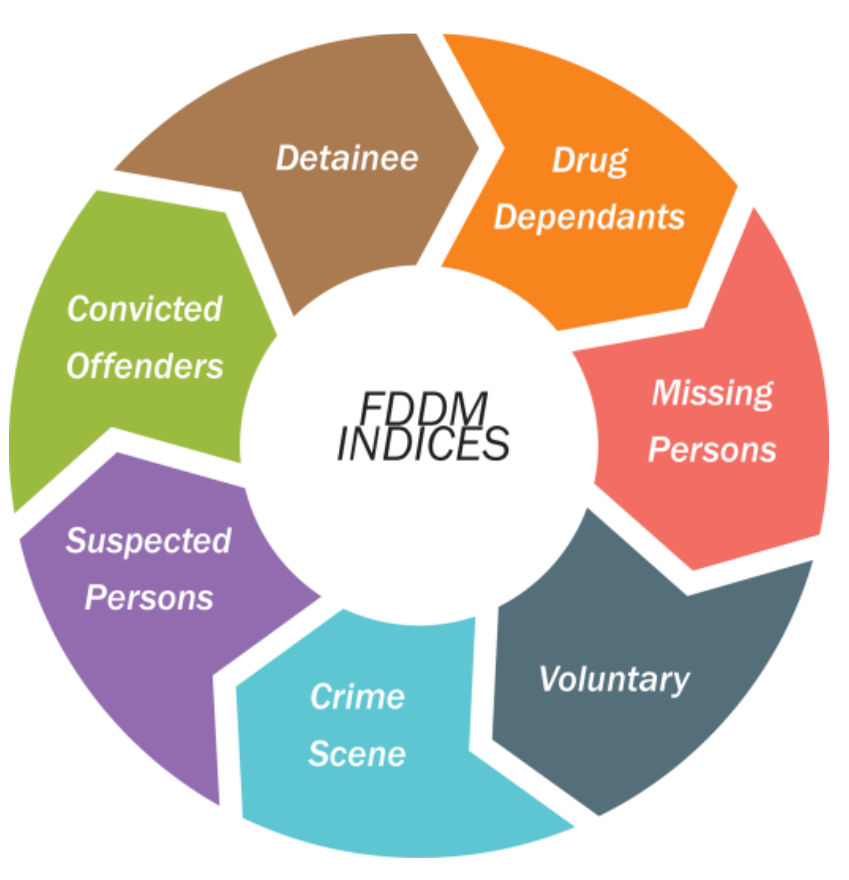

Figure 5. FDDM Indices.

\subsection{Collaboration Between RMP \& KIMIA}

The collaboration between RMP and KIMIA has been established since 2012 when Forensic DNA Databank Malaysia was developed. This collaboration strengthens with periodical meetings to discuss problems encountered and information sharing between two agencies especially updates on the FDDM system and cases solved.

\section{Materials \& Methods}

\subsection{Reference Samples}

One of the DNA profile categories in the FDDM is known as a reference sample or 'known sample' which are analyzed by DNA analysts from the RMP DNA laboratory. DNA sampling in RMP is using buccal samples that were collected in the designated room known as Pusat Identifikasi Forensik Setempat (PIFOS) which is located at each 156 district police headquarters. All samples collected by using "BODE buccal DNA collector" was sticked with a barcode and supplied with an information card to label the samples either from a suspected, convicted offender, detainee, drug dependent, voluntary or next of kin (NOK) for missing person.

This buccal DNA collector was obtained from the Bode Technology Group (TBTG). This is an easy-to-use noninvasive device designed for a collection of buccal cells from the inside of the cheek for the purpose of human DNA identification analysis. The standard packaging of the Buccal DNA Collection Kit includes BODE Buccal DNA Collector, DNA transport pouch with desiccant, a glove, a mask, barcode and information card. The information card contains information related to the name of the sample giver, identification card or passport number of the sample giver, address and race of the sample giver, offence section of the sample giver, the officer who took the sample and the signature of the sample giver.

All samples are then sent to the RMP DNA laboratory where has been accredited with MS ISO / IEC 17025 since 2013 by the Department of Standards Malaysia.

All buccal samples received from the district were registered using Laboratory Information Management System (LIMS). Then all the DNA samples are assigned to the analyst for analysis purposes $[6,7]$.

\subsection{Crime Scene Samples}

Another DNA profile category in the FDDM is called the 'unknown samples' where the samples are collected from crime scenes and analyze by chemists and DNA Analysts from KIMIA.

At KIMIA, they analyze all types of DNA samples collected from the crime scene such as blood, hair, bone and semen which have been sent by Investigating Officers (IOs) from all over the district.

The DNA profiles generated through DNA analysis will be uploaded to FDDM by DNA Databank Officers. If there are any positive DNA profile matches, these officers would provide the related information to the investigating officers for further investigation.

\subsection{DNA Analysis Process}

Both of the DNA laboratories either RMP or KIMIA are using a direct amplification kit known as Globalfiler Express (GFE) for DNA analysis of known samples. Direct PCR is a method of forensic DNA which amplification happen directly from a sample without performing DNA isolation and purification steps. DNA analysis for crime scene samples is analyzed according to the type of the samples either blood, hair, semen, bone or etc. following international recommendations.

In the RMP DNA laboratory, the analysis of the samples using a 96-well plate. This plate was added with 2.0ul isolation buffer (Prep $\mathrm{n}$ Go) for each well. Then $1.2 \mathrm{~mm}$ samples/blank were punched into a 96-well plate using BSD 600 Duet Semi-Automated Dried Sample Punch Instrument. Every plate consists of 89 samples, (1) blank, (1) positive control, (1) negative control and (4) Allelic Ladder [8, 10, 13].

The samples were amplified using the Globalfiler Express (GFE). Amplification was performed on the ABI Gene Amp 9700 PCR System for 25 cycles. 3 ul positive control of DNA 007 was added into (1) well of the plate. The Globalfiler Express Kit is a multiplex assay using 24 loci: D13S317, D7S820, D5S818, CSF1PO, D1S656, D12S391, D2S441, D10S1248, D18S51, FGA, D21S11, D8S1179, VWA, D16S539, TH01, D3S1358, AMEL, D2S1338, D19S433, DYS391, TPOX, D22S1045, SE33 AND Y-specific insertion/ deletion locus (Y Indel) $[8,10,13,14]$.

The amplified products were analyzed using ABI 3500XL Genetic Analyzer (Life Technology). 1ul PCR product, 9.5ul HIDI Formamide and 0.5ul Genescan Liz Size Standard 2.0 (Thermo Fisher Scientific) were used for the post PCR 
process. 1ul Allelic Ladder also included in every run on the 96-well plate. Then, samples were denatured for $3 \mathrm{~min}$ at $95^{\circ} \mathrm{C}$ and afterwards cooled on ice for $3 \mathrm{~min}$. Electrophoresis was performed using a 24-cm capillary array, POP-4 Polymer and standard injection parameters with validated protocols. Data obtained were analyses with Gene Mapper IDX Software version 1.4 (Life Technology) using the validated threshold $[8,10,13]$.

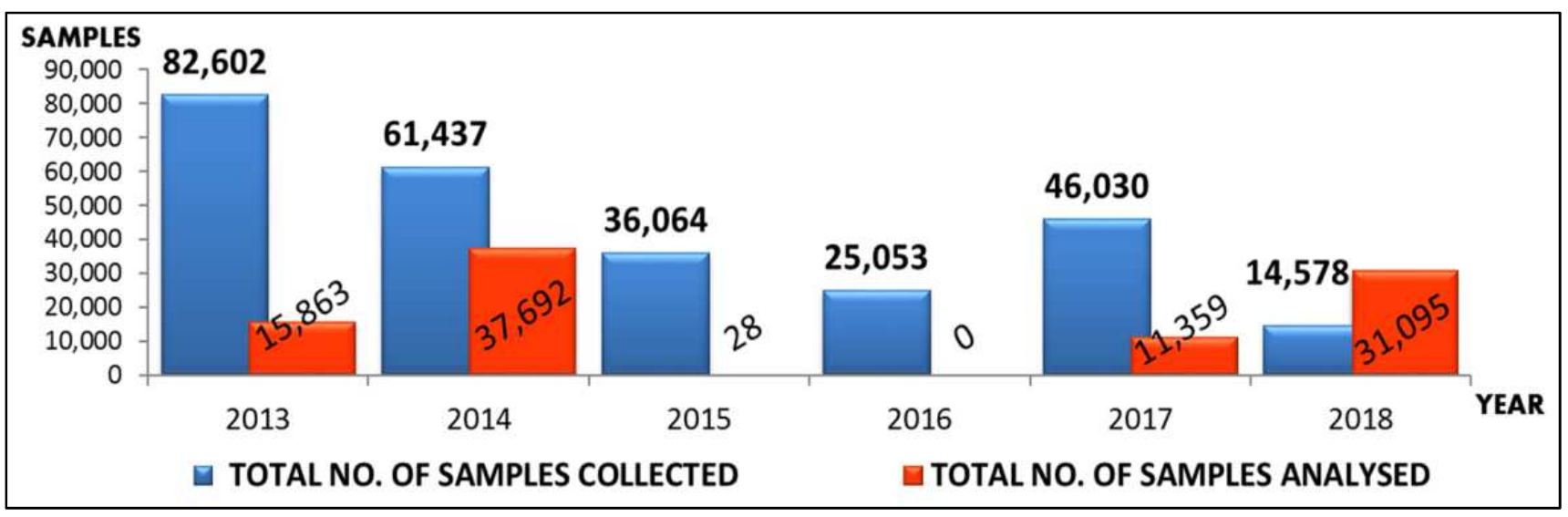

Figure 6. Total Number of Samples Collected and Analysed (2013-2018).

\section{Results}

Figure 6 showed the highest sample collected was in 2013, which is the year Malaysia started to set up a DNA database. The bar chart showed the total number of DNA samples collected from the year 2013 until 2018, which is 265,764. From that amount, only 96,037 samples were analyzed.

While the pie chart showed the breakdown of the sample status from the year 2013 until 2018. The samples collected exceeded $50 \%$ of the total FDDM profiles. However, the samples analysed were only $36.1 \%$ of the total number of the samples collected. This is due to an insufficient supply of reagents for the analysis, which resulted in the number of backlog samples. The total number of profiles that have been uploaded into the system is $85.75 \%$ of the total samples analysed. From these profiles, there were 33 profile matches (HIT).

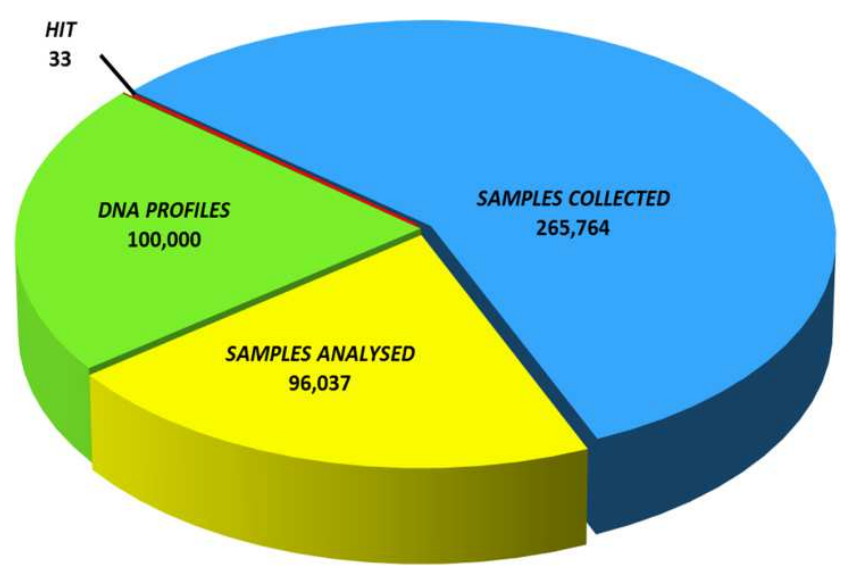

Figure 7. Samples Collected, Samples Analysed, Profiles in FDDM and Profiles Matches (2013-2018).

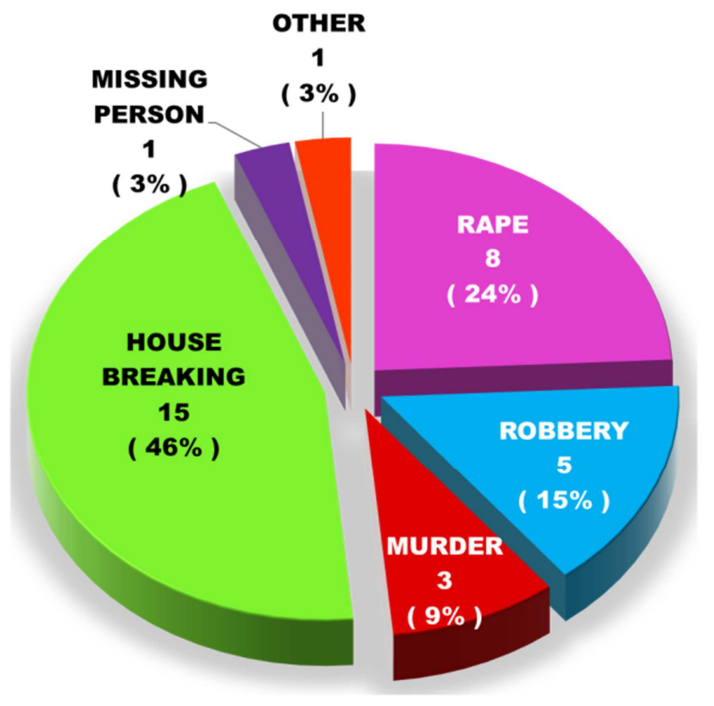

Figure 8. Case categories and Classification.

During the 6 years (2013 to 2018) of the establishment of FDDM, the number of DNA matching cases also increased from year to year. Figure 8 showed the DNA match categorised by offences. The highest cases were house breaking at $46 \%$, rape at $24 \%$ and followed by robbery $15 \%$.

\section{Success Stories in Crime-solving and Body Identification}

\subsection{Case Number 1; Triple Murder}

The crime took place in August 2013 where a family of three (3) which includes a 2-year-old baby were murdered at their home in a rural area in Selangor. All the bodies were found in different sections of the house; namely in the living room, kitchen and master bedroom. All of them were discovered by other family members aged 7-years old upon returning from school. Investigation at the crime scene had 
found several evidences including bloodstains, and all the exhibits were sent for DNA analysis at KIMIA.

An unknown male profile was developed from the evidence and labelled as "Unknown" which could be a possible suspect for the murder. In 2017, the "Unknown" profile was uploaded to FDDM and a positive DNA match was found. It matched a 22-year-old Indian male who was a suspect in a gang and arrested under an operation by the police. Further, investigation on the suspect had led to an arrest of his accomplice. Both suspects were prosecuted for murder.

\subsection{Case Number 2; Body Identification}

A dead body was found in the city centre of Kuala Lumpur in 2016 without any identification initials and documents. The body was sent for autopsy and his DNA was profiled then stored in a DNA database for future references. In 2017, the profile was found to match from a resident in the Cure and Care Rehabilitation Centre (CCRC) in Kedah. From this information, the family of the victim was able to be identified and notified.

\section{The Way Forward}

Continuous transformation needs to be implemented to ensure that within the next 5 to 10 years, either in RMP or KIMIA, more comprehensive, efficient and high-tech DNA laboratories would be successfully developed.

The MS ISO/ IEC 17025:2005 Accreditation for RMP DNA Laboratory is currently gearing up for a new version of MS ISO/ IEC 17025:2017 Accreditation, which is scheduled to be implemented. Spanning the 21st century, RMP and KIMIA are always positive in ensuring that the direction of FDDM constantly evolves from time to time in line with the rapid development of DNA Technology.

The functionality of the DNA databank will also achieve a more effective and progressive paradigm shift. The effectiveness of DNA databases is not necessarily related to their size but more to the proportion of the data in the database [5].

Moving towards FDDM's direction, the capabilities of DNA laboratories in RMP and KIMIA should be enhanced through the implementation of the latest equipment and using automated systems. This can indirectly increase the productivity of the number of DNA samples analyzed, and minimize the number of backlogs. The aim of the FDDM for the next 5 to 10 years is to achieve at least $25 \%$ matching cases which means every 1 of 4 DNA samples analyses would be able to get a match and solve the cases.

\section{Conclusion}

The DNA database in Malaysia is the first step to embrace the technology in a criminal investigation. The existence of this database is a sign that Malaysia is moving forward to reduce crime and aid the Royal Malaysia Police in gaining leads for their investigation. The DNA database has a big potential as a crime- solving tool that can increase the rate of criminal prosecution and as a prevention measure if the perpetrator can be identified as early as possible.

\section{Acknowledgements}

We would like to thank Analisa Resources for the help and supports provided and all officers from the DNA Databank Division (D13), Criminal Investigation Department, and Royal Malaysia Police for their contribution in building up the DNA Databank especially to the following officers: Rosdiana Hanim Mohd Diah, Victor Ananth A/L Paramanath, Abdul Rashid Muningin, Fellino Sidin, for their supports of this journal.

\section{References}

[1] Aaron Opoku Amankwaa, Carole McCartney. 2019. The effectiveness of the UK national DNA database. Forensic Science International: Synergy 1 (2019) 45-55.

[2] Aline C. Minervino, Ronaldo C. Silva Jr., Mariana F. da Mota, Cecilia H. F. Matte, Daniela Koshikene, Joao Paulo S. C. Oliveira, Tatiana Hessab, Bruno R. Trindade, Guiherme S. Jacques, Samuel T. G. Ferreira, Elianeide A. de Lima, Claudio Cesar Felipe. 2019. Increasing convicted offender genetic profiles in the Brazilian National DNA Database-Legislation, projects and perspectives. Forensic Science International: Genetics Supplement Series 7 (2019) 575-577.

[3] Akta Identifikasi DNA 2009 dan Peraturan-Peraturan Identifikasi DNA 2012. (Akta 699). (2013). Percetakan National Malaysian Berhad (PNMB).

[4] Dennis Y. Wang, Siddhita Gopinath, Robert E. Lagacé, Wilma Norona, Lori K. Hennessy, Marc L. Short, Julio J. Mulero. 2015. Developmental validation of the GlobalFiler $^{\mathbb{B}}$ Express PCR Amplification Kit: A 6-dye multiplex assay for the direct amplification of reference samples. Forensic Science International: Genetics 19 (2015) 148-155.

[5] Eloisa Auler Bittencourt, Edna Sadayo Miazato Iwamura. 2019. Brazilian DNA database-Establishment, legislation and accreditation. Forensic Science International: Genetics Supplement Series 7 (2019) 422-423.

[6] James W. Schumm, Eun Young Song, Martha Burger, Jangbir Sangha. 2004. Collecting and processing buccal cell samples. International Congress Series 1261 (2004) 550-552.

[7] Laura Locarno, Dante Corradi, Miguel Marino. 2019. Start-up of the criminal genetic database in Mendoza, Argentina. Forensic Science International: Genetics Supplement Series 7 (2019) 100-102.

[8] M. Caputo, M. C. Bobillo, A. Sala, D. Corach. 2017. Optimizing direct amplification of forensic commercial kits for STR determination. Journal of Forensic and Legal Medicine 47 (2017) 17-23.

[9] N. Booderm, D. Suriyanratakorn, C. Wongvoravivat, S. Sangpueng, A. Nettakul, W. Waiyawuth. 2017. Effectiveness of CIFS DNA database in Thailand. Forensic Science International: Genetics Supplement Series 6 (2017) e585-e586. 
[10] N. Gouveia, P. Brito, A. Serra, F. Balsa, L. Andrade, M. São Bento, P. Cunha, V. Bogas, V. Lopes, M. J. Porto. 2015. Direct amplification of reference samples with Globalfiler ${ }^{B}$ PCR Amplification Kit. Forensic Science International: Genetics Supplement Series 5 (2015) e135-e137.

[11] Nongnuch Booderm, Danuphol Suriyanratakorn, Sireethron Sangpueng, Chalampoo Wongvoravivat, Worawee Waiyawuth. 2019. Utilization of the CIFS DNA database to monitor recidivism. Forensic Science International: Genetics Supplement Series 7 (2017) e585-e586.

[12] Pia Struyf, Sabine De Moor, Christophe Vandeviver, Bertrand Renard, Tom Vander Beken. 2019. The effectiveness of DNA databases in relation to their purpose and content: A systematic review. Forensic Science International 301 (2019) 371-381. 5 .
[13] Shahida Flores, Jie Sun, Jonathan King, Bruce Budowle. 2014. Internal validation of the GlobalFiler ${ }^{\mathrm{TM}}$ Express PCR Amplification Kit for the direct amplification of reference DNA samples on a high-throughput automated workflow. Forensic Science International: Genetics 10 (2014) 33-39.

[14] Tamyra R. Moretti, Lilliana I. Moreno, Jill B. Smerick, Michelle L. Pignone, Rosana Hizon, John S. Buckleton, Jo Anne Bright, Anthony J. Onorato. 2016. Population data on the expanded CODIS core STR loci for eleven populations of significance for forensic DNA analyses in the United States. Forensic Science International: Genetics 25 (2016) 175-181.

[15] Zlatko Jakovski, Renata Jankova Ajanovska, Aleksandar Stankov, Verica Poposka, Natasa Bitoljanu, Viktorija Belakaposka. 2017. The Power of Forensic DNA Data Bases in Solving Crime Cases. Forensic Science International: Genetics Supplement Series 6 (2017) e275-e276. 